\title{
Establishment of a Stable Acute Drug-Induced Liver Injury Mouse Model by Sodium Cyclamate
}

\author{
Quan Zhou ${ }^{1,2}$, Zhongtian Peng ${ }^{2}$, Xialing Huang $\mathbb{D}^{2,3}$
}

'Department of Infectious Diseases, The First Hospital of Changsha, Changsha, Hunan, 410000, People's Republic of China; ${ }^{2}$ Department of Infectious Diseases, The First Affiliated Hospital, Hengyang Medical School, University of South China, Hengyang, Hunan, 42I00I, People's Republic of China; ${ }^{3}$ Department of Infectious Diseases, Leiyang People's Hospital, Leiyang, Hunan, 421800, People's Republic of China

Correspondence: Zhongtian Peng, Department of Infectious Diseases, The First Affiliated Hospital, Hengyang Medical School, University of South China, Hengyang, Hunan, 42 I00I, People's Republic of China, Tel +86 I3873488377, Email hncspzt@I63.com; Xialing Huang, Department of Infectious Diseases, Leiyang People's Hospital, Leiyang, Hunan, 421800, People's Republic of China, Tel +86 I5200522 I85, Email I25695234@qq.com

Objective: To establish a stable acute DILI mouse model and explore its possible pathogenesis.

Methods: Mice were randomly divided into control, low-dose, middle-dose and high-dose sodium cyclamate groups. Mice in the model group were intraperitoneally injected with corresponding doses of sodium cyclamate, and in the control group intraperitoneally injected with $0.9 \%$ normal saline. The toxic effects of sodium cyclamate on liver, heart, kidney were evaluated by biochemical index level and histomorphologically observed. The expression of TNF- $\alpha$ and IL- $1 \beta$ were measured by immunohistochemistry.

Results: 1 . The level of ALT in the low-dose and middle-dose groups at $24 \mathrm{~h}, 72 \mathrm{~h}, 120 \mathrm{~h}$ and $168 \mathrm{~h}$ were increased, also in the highdose group at $24 \mathrm{~h}, 72 \mathrm{~h}$ and $120 \mathrm{~h}$. The level of AST in the low-dose group at $72 \mathrm{~h}, 120 \mathrm{~h}, 168 \mathrm{~h}$ and in the middle-dose group at $168 \mathrm{~h}$ were increased, also in the middle-dose and high-dose groups at $24 \mathrm{~h}, 72 \mathrm{~h}$ and $120 \mathrm{~h}$. The levels of CK, CK-MB and cTnT in the lowdose and middle-dose groups at $168 \mathrm{~h}$ were increased, also in the high-dose group at $24 \mathrm{~h}, 72 \mathrm{~h}$ and $120 \mathrm{~h}$. 2 . The damage of hepatocytes increased with the increase of sodium cyclamate dosage and treated time. 3 . At $120 \mathrm{~h}$, the IOD/Area of TNF- $\alpha$ and IL- $1 \beta$ positive expression increased in the liver tissues with the increase of the dosage. In the heart and kidney tissues, the IOD/Area of TNF- $\alpha$ and IL-1 $\beta$ positive expression in the high-dose group increased significantly. In the kidney tissues, the IOD/Area of IL-1 $\beta$ positive expression in the middle-dose group increased significantly.

Conclusion: Sodium cyclamate-induced acute DILI mouse model can be established by intraperitoneal injection of $6000 \mathrm{mg} / \mathrm{kg} / \mathrm{day}$ sodium cyclamate for 5 days successfully. The toxicity of sodium cyclamate to liver showed a dose-response and time-response relationship. Sodium cyclamate induced liver, heart and kidney injury closely related to the inflammatory response mediated by TNF- $\alpha$ and IL-1 $\beta$.

Keywords: sodium cyclamate, acute liver injury, animal model, TNF- $\alpha$, IL-1 $\beta$

\section{Introduction}

With all kinds of drugs used widely, drug-induced liver injury (DILI) has become a hot and difficult research topic in liver Diseases. It is defined as "liver damage caused by the drug or its metabolites, also including caused by hypersensitivity or reduced tolerance of the drug". It is reported that $12.2 \%$ of the hospitalized patients in China have acute liver failure caused by hepatotoxic drugs. ${ }^{2}$ As the diagnosis of DILI is quite challenging, in fact, the incidence of DILI is much higher than the existing statistics. ${ }^{3}$ The pathogenesis of DILI is complex, which may be related to endoplasmic reticulum and mitochondrial stress, genetic susceptibility, environment and other factors. ${ }^{4}$ However, the current animal model used for DILI research is not mature and the related mechanism research is not clear. Therefore, it is of great practical significance to establish a stable acute DILI mouse model and explore its possible pathogenesis.

As a food additive, sodium cyclamate has been added to hot strips by illegal businesses, and its excessive use has caused liver damage. ${ }^{5}$ Sodium cyclamate is a white crystalline. Its sweetness is about $40-50$ times that of sucrose, and it is a non nutritive sweetener. ${ }^{6}$ According to the toxicological study of sodium cyclamate, long-term use has different degrees of damage to liver, 
kidney, heart and gastrointestinal tract, which can cause liver cell necrosis, renal interstitial calcium deposition, myocardial calcification, coronary arteriosclerosis, bladder cancer and testicular atrophy. ${ }^{7}$

In previous studies, the establishment of liver injury animal model mainly considered the effect of the drug dosage and treated time, did not explore the damage of other organs, its stability is worth studying. Thus, the purpose of this study is to establish a stable acute DILI mouse model with obvious damage to liver but no obvious damage to other organs.

At present, there is no specific diagnostic marker of DILI in clinic. ${ }^{8}$ The diagnosis of DILI is a subjective evaluation based on clinical experience and existing data, which is to inquire about the history of disease, the time relationship between medication and index abnormality, exclude other possible causes of liver damage. ${ }^{9}$ Generally, the time of drug use is related to the time of biochemical index change. Most biochemical indexes can be recovered quickly and thoroughly after drug withdrawal, which is the main index of DILI detection. ${ }^{10}$ Alanine transaminase (ALT) and artaspate transaminase (AST) were released into the blood in different degrees. DILI with clinical significance was defined as ALT $>3$ times of the upper limit of normal (ULN). When serum level of ALT increased, it suggested that hepatocyte membrane was damaged. When serum level of AST increased, it suggested that mitochondrial was damaged and hepatocyte serious was damaged, usually positively related to the severity of the disease. If the total bilirubin (TBIL) $>2$ times of the ULN, it is considered as severe liver injury. ${ }^{11}$ Creatine kinase (CK) and creatine kinase-MB (CK-MB) are classic biomarkers of myocardial cell injury. The increased serum level of CK and CK-MB can judge the severity of myocardial injury. ${ }^{12}$ Cardiac troponin $\mathrm{T}$ (cTnT) is a calcium binding protein, which is unique to myocardium, with high sensitivity and specificity. ${ }^{13}$ The clinical diagnosis method for nephrotoxicity is based on the diagnosis standard of acute renal injury, which means that serum creatinine ( $\mathrm{SCr}$ ) $>0.3 \mathrm{mg} / \mathrm{dl} \mathrm{or}$ 1.5 times of the baseline within 48 hours, which can show azotemia and systemic symptoms. ${ }^{14}$ Therefore, ALT, AST, TBIL, direct bilirubin (DBIL), CK, CK-MB, cTnT, SCr and blood urea nitrogen (BUN) levels were used as indicators of liver, heart and kidney damage caused by short-term use of sodium cyclamate.

\section{Materials and Methods}

\section{Mice}

A total of 96 Kunming mice (48 male and 48 female; age, 4-6 weeks; weight, 18-25 g) were provided by the Changsha tianqin Biotechnology Co., Ltd. [Changsha, China; certificate no. SCXK (Xiang) 2014-0011]. These research animals were maintained in standard atmospheric pressure, a 12/12-h light/dark cycle, room temperature $22 \pm 2{ }^{\circ} \mathrm{C}, 50 \pm 10 \%$ humidity, ammonia concentration $\leq 14 \mathrm{mg} / \mathrm{m}^{3}$, and noise $\leq 60 \mathrm{~dB}$. These mice were randomly raised in cages with 6 mice of the same sex in each cage. Animals had access to food and water ad libitum. Animals were fasted overnight with free access to water prior to the commencing of experiments. All animal experimental procedures were performed in accordance with the Guidelines for Animal Experiments of University of South China (Hunan, China) and were approved by the Institutional Ethics Committee for University of South China (Hunan, China; ethical approval No. 2019-AR-06).

\section{Drugs and Treatments}

Sodium cyclamate was purchased from Fangda additive (Yangquan) Co., Ltd. Sodium cyclamate was dissolved in sterile distilled water. 7 days following adaption, the mice were randomly divided into four groups: i) the control group, in which mice were injected intraperitoneally with $0.9 \%$ normal saline (NS) for 7 days; ii) the low-dose sodium cyclamatetreated group, in which mice were injected intraperitoneally with $3000 \mathrm{mg} / \mathrm{kg} /$ day sodium cyclamate for 7 days; iii) the middle-dose sodium cyclamate-treated group, in which mice were injected intraperitoneally with $6000 \mathrm{mg} / \mathrm{kg} / \mathrm{day}$ sodium cyclamate for 7 days and iv) the high-dose sodium cyclamate-treated group, in which mice were injected intraperitoneally with $12,000 \mathrm{mg} / \mathrm{kg} /$ day sodium cyclamate for 7 days.

\section{Specimen Collection}

$1.5 \mathrm{~mL}$ volume of blood was collected from the medial canthus vein of the 6 anesthetized mice in each group by intraperitoneal injection of $10 \%$ chloral hydrate $(4400 \mathrm{mg} / \mathrm{kg})$ at $24 \mathrm{~h}, 72 \mathrm{~h}, 120 \mathrm{~h}$ and $168 \mathrm{~h}$ respectively. Animals were euthanized by sodium pentobarbital overdose $(100 \mathrm{mg} / \mathrm{kg}$, intravenous injection) after blood collected. The liver, heart and kidney tissues were removed after euthanized. After washing these tissues surface with $0.9 \%$ NS, the same part of 
these tissues were put into $1.5 \mathrm{~mL}$ EP tubes, which were fixed using $4 \%$ paraformaldehyde for pathological examination. Moreover, another part of the liver tissue was taken out and put into $1.5 \mathrm{~mL}$ EP tubes, which were fixed using $2.5 \%$ glutaraldehyde for electron microscopy.

\section{Laboratory Reagents and Instruments}

CTnT (Roche), primary antibodies [tumor necrosis factor- $\alpha$ (TNF- $\alpha$ ) antibody (PTG) and interleukin-1 $\beta$ (IL-1 $1 \beta$ ) antibody (Abcam)], DAB kit (ZSGB-BIO), automatic biochemical analyzer (7600; Hitachi), automatic electrochemiluminescence immunoassay (cobas e601; Roche), optical microscope (BA210T; Motic), transmission electron microscopy (HT7700; Hitachi) and Image-Pro image analysis system (Wellbio Laboratories).

\section{Assay of Serum Indices}

Serum ALT, AST, TBIL, DBIL, CK, CK-MB, SCr and BUN were analyzed using the automatic biochemical analyzer. Serum cTnT was analyzed using the automatic electrochemiluminescence immunoassay. All the methods and procedures were determined according to the manufacturer's instructions.

\section{Histological Examination}

The liver, heart and kidney tissues were fixed in $4 \%$ paraformaldehyde at $4{ }^{\circ} \mathrm{C}$ for 7 days, then embedded in paraffin. Tissue sections $(5 \mu \mathrm{m})$ were stained with hematoxylin and eosin to examine the morphology of the liver, heart and kidney. ${ }^{15}$

\section{Transmission Electron Microscopy}

The liver tissues were cut into $1 \mathrm{~mm}^{3}$ sections and fixed in $2.5 \%$ glutaraldehyde to observe alterations in the ultrastructure of hepatocyte under electron microscopy. ${ }^{16}$

\section{Immunohistochemistry}

The paraffin-embedded tissues were made into sections ( $5 \mu \mathrm{m}$ in thickness), placed in $42{ }^{\circ} \mathrm{C}$ warm water for spreading, collected using slides, baked in $60{ }^{\circ} \mathrm{C}$ for $30-60 \mathrm{~min}$, and prepared into paraffin tissue sections. Next, the paraffin tissue sections were sequentially soaked in xylene solution and graded ethanols, conventionally deparaffinized and hydrated. Thereafter, they were immersed in citric acid buffer ( $\mathrm{pH}$ 6.0) and heated in a microwave for $23 \mathrm{~min}$, then got them out, and cooled them to room temperature for complete antigen retrieval. After rinsing, the specimens were dropwise added with endogenous peroxidase blocker for reaction for $10 \mathrm{~min}$, followed by rinsing. Subsequently, the specimens were added with anti-TNF- $\alpha$ primary antibody (1:400) and anti-IL-1 $\beta$ primary antibody (1:400) and placed in a refrigerator at $4{ }^{\circ} \mathrm{C}$ overnight. The next day, the specimens were rinsed, dropwise added with secondary antibody solution in $37^{\circ} \mathrm{C}$ for 30 min of incubation, thoroughly rinsed and followed by color development with diaminobenzidine (DAB) added in drops. Lastly, the nuclei were counterstained with hematoxylin, mounted and observed. ${ }^{17}$

\section{Statistical Analysis}

The statistical analysis was performed using the SPSS 25.0 software. The data were displayed as the mean \pm standard deviation (SD). One-way ANOVA was applied to assess the significant differences between the groups. P value lower than $0.05(\mathrm{P}<0.05)$ was considered for significant differences.

\section{Results}

\section{Symptoms and Mortality}

The control group mice had good mental state, sensitive activity, good appetite, gentle personality, and granular stool. The sodium cyclamate-treated group mice activity was significantly reduced, poor appetite and irritable personality. With the increase of sodium cyclamate dosage and treated time, the changes were more obvious, the stool became softer and looser, and the high-dose $(12,000 \mathrm{mg} / \mathrm{kg} /$ day, intraperitoneally) group even had watery stool. 
The total mortality of the mice in the low-dose $(3000 \mathrm{mg} / \mathrm{kg} / \mathrm{day}$, intraperitoneally) and the middle-dose $(6000 \mathrm{mg} / \mathrm{kg} /$ day, intraperitoneally) groups were $4.17 \%$, but in the high-dose $(12,000 \mathrm{mg} / \mathrm{kg} / \mathrm{day}$, intraperitoneally) group reached $37.5 \%$. All mice in the control group were viable. The mice in the high-dose $(12,000 \mathrm{mg} / \mathrm{kg} / \mathrm{day}$, intraperitoneally) group began to died at $24 \mathrm{~h}$ of intraperitoneal injection, and the death time was earlier with the increase of sodium cyclamate dosage (Table 1). These result showed that sodium cyclamate effected the normal appetite, spirit and activity of mice. It is lethal when it reached a measure of sodium cyclamate dosage and treated time.

\section{Effect on Body Weights}

The weight changes were recorded from before adaptive feeding to sodium cyclamate-treated at $168 \mathrm{~h}$. With the increase of sodium cyclamate dosage and treated time, the mice weight gradually decreased. Compared with the parallel control group, the mice weight in the middle-dose $(6000 \mathrm{mg} / \mathrm{kg} /$ day, intraperitoneally) and the high-dose $(12,000 \mathrm{mg} / \mathrm{kg} / \mathrm{day}$, intraperitoneally) groups at $24 \mathrm{~h}$ decreased significantly $(\mathrm{P}<0.01)$, also in the all sodium cyclamate-treated groups at $72 \mathrm{~h}$, $120 \mathrm{~h}$ and $168 \mathrm{~h}(\mathrm{P}<0.01)$. There was no significant difference in the weight of mice before adaptive feeding in each group $(\mathrm{P}>0.05)$. These results suggested that sodium cyclamate could induce weight loss in mice. It has low energy and affects the normal appetite of mice (Table 2 and Figure 1).

\section{Evaluation of Liver Injury by Serum Analysis}

The differences in the serum levels of ALT, AST, TBIL and DBIL were determined among the 4 groups. The liver injury of each sodium cyclamate-treated mice showed different degrees. Compared with the parallel control group, the serum level of ALT of the low-dose $(3000 \mathrm{mg} / \mathrm{kg} / \mathrm{day}$, intraperitoneally) group increased at $24 \mathrm{~h}$ and $72 \mathrm{~h}(\mathrm{P}<0.05)$, the middledose $(6000 \mathrm{mg} / \mathrm{kg} /$ day, intraperitoneally) and the high-dose $(12,000 \mathrm{mg} / \mathrm{kg} / \mathrm{day}$, intraperitoneally) groups at $24 \mathrm{~h}$ and $72 \mathrm{~h}$ were increased significantly $(\mathrm{P}<0.01)$, also in all sodium cyclamate-treated group at $120 \mathrm{~h}$ and $168 \mathrm{~h}(\mathrm{P}<0.01)$. The serum level of AST of the middle-dose $(6000 \mathrm{mg} / \mathrm{kg} /$ day, intraperitoneally) and the high-dose $(12,000 \mathrm{mg} / \mathrm{kg} / \mathrm{day}$, intraperitoneally) groups at $24 \mathrm{~h}$ were increased significantly $(\mathrm{P}<0.01)$, also in all sodium cyclamate-treated group at $72 \mathrm{~h}, 120 \mathrm{~h}$ and $168 \mathrm{~h}(\mathrm{P}<0.01)$. Compared with $24 \mathrm{~h}$ in each group, the serum level of ALT of the low-dose $(3000 \mathrm{mg} / \mathrm{kg} /$ day, intraperitoneally) group at $120 \mathrm{~h}$ and $168 \mathrm{~h}$, the middle-dose $(6000 \mathrm{mg} / \mathrm{kg} /$ day, intraperitoneally) group at $72 \mathrm{~h}, 120 \mathrm{~h}$ and $168 \mathrm{~h}$, the high-dose $(12,000 \mathrm{mg} / \mathrm{kg} / \mathrm{day}$, intraperitoneally) group at $72 \mathrm{~h}$ and $120 \mathrm{~h}$ were increased significantly $(\mathrm{P}<$ 0.01). The serum level of AST of the low-dose $(3000 \mathrm{mg} / \mathrm{kg} /$ day, intraperitoneally) and the middle-dose (6000 mg/kg/ day, intraperitoneally) groups at $72 \mathrm{~h}, 120 \mathrm{~h}, 168 \mathrm{~h}$ were increased significantly $(\mathrm{P}<0.01$ ), also in the high-dose $(12,000 \mathrm{mg} / \mathrm{kg} / \mathrm{day}$, intraperitoneally) group at $72 \mathrm{~h}$ and $120 \mathrm{~h}(\mathrm{P}<0.01)$. There was no significant difference in the

Table I Death of Mice in Each Group (n)

\begin{tabular}{|l|c|c|c|c|c|}
\hline Groups & $\mathbf{2 4 h}$ & $\mathbf{7 2 h}$ & $\mathbf{I 2 0 h}$ & I68h & Total Mortality (\%) \\
\hline Control group & 0 & 0 & 0 & 0 & 0 \\
Low-dose group & 0 & 0 & 1 & 0 & 4.17 \\
Middle-dose group & 0 & 1 & 0 & 0 & 4.17 \\
High-dose group & 3 & 5 & I & - & 37.50 \\
\hline
\end{tabular}

Note: - , no mice survived in the high-dose group after $168 \mathrm{~h}$.

Table 2 Weight of Mice in Each Group (g)

\begin{tabular}{|l|c|c|c|c|c|}
\hline Groups & Before Adaption & $\mathbf{2 4 h}$ & $\mathbf{7 2 h}$ & $\mathbf{I 2 0 h}$ & $\mathbf{I 6 8 h}$ \\
\hline Control group & $21.08 \pm I .44$ & $29.47 \pm 1.96$ & $31.06 \pm 2.59$ & $32.28 \pm 2.21$ & $34.44 \pm 1.44$ \\
Low-dose group & $20.90 \pm 0.84$ & $29.31 \pm 2.77$ & $28.46 \pm 0.89 * *$ & $27.15 \pm 1.40^{* *}$ & $25.24 \pm 0.58^{* *}$ \\
Middle-dose group & $20.64 \pm 0.82$ & $27.96 \pm 0.70^{* *}$ & $27.02 \pm 1.97 * *$ & $25.74 \pm 1.07 * *$ & $24.80 \pm 1.06^{* *}$ \\
High-dose group & $20.48 \pm 0.96$ & $26.76 \pm 1.05^{* *}$ & $25.15 \pm 0.8 I^{* *}$ & $23.43 \pm 0.70^{* *}$ & - \\
\hline
\end{tabular}

Notes: Data are presented as mean \pm standard deviation; $* * \mathrm{P}<0.01$ vs parallel control group; - , no specimen collected. 


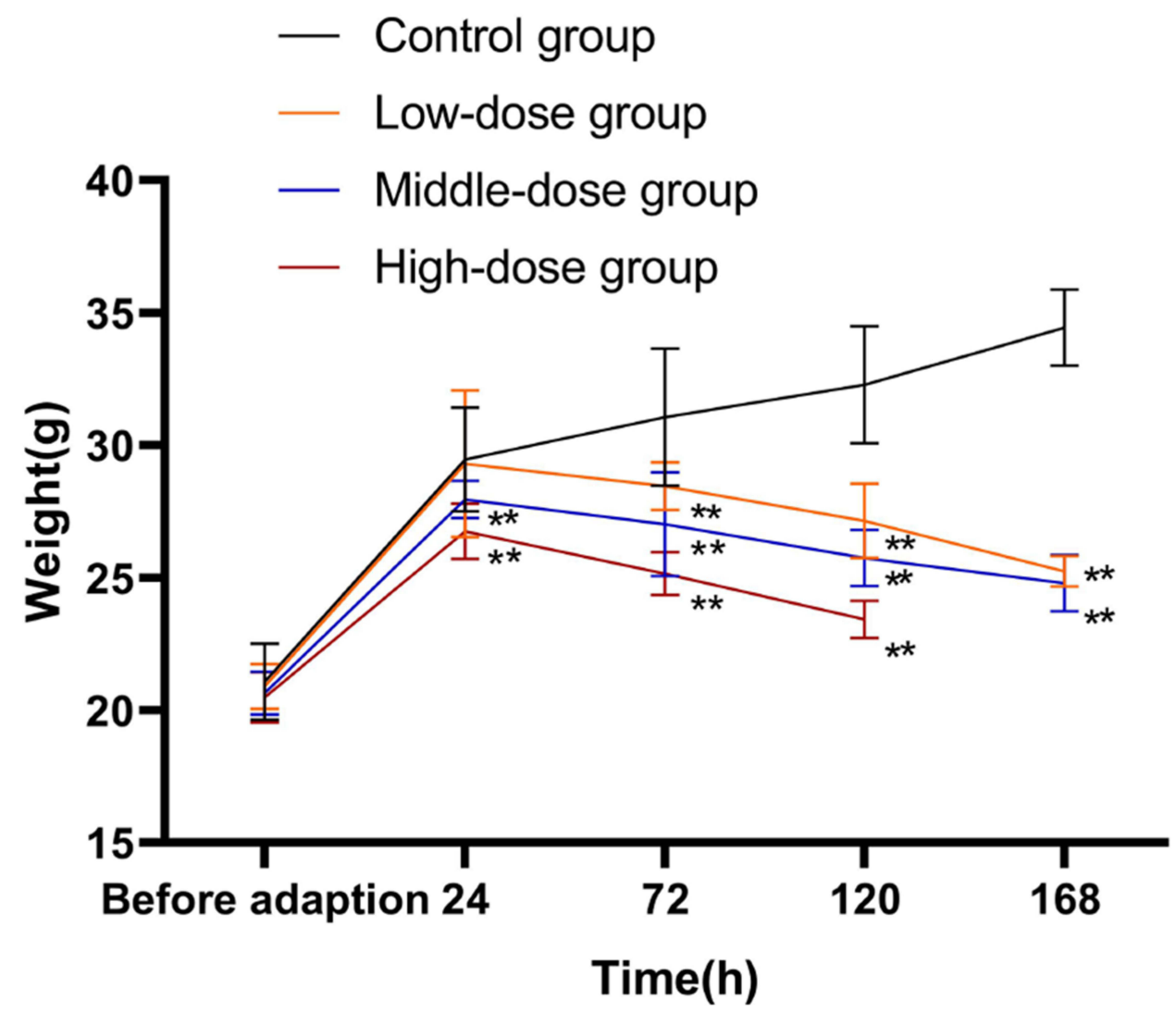

Figure I Effect of sodium cyclamate on mice weight. The weight changes were recorded from before adaption to sodium cyclamate-treated at $168 \mathrm{~h}$. Values are the mean \pm standard deviation. $* * \mathrm{P}<0.01$ vs parallel control group.

serum levels of ALT and AST between the control groups ( $\mathrm{P}>0.05$; Tables 3 and 4, Figure $2 \mathrm{~A}$ and $\mathrm{B})$. But in the aspect of cholestasis, there was no correlation between the serum levels of TBIL and DBIL with the sodium cyclamate dosage and treated time in the experimental period. Compared with the parallel control group and $24 \mathrm{~h}$ in each group, there were no significant difference between the serum levels of TBIL and DBIL in each group ( $P>0.05$; Tables 5 and 6 and Figure $2 \mathrm{C}$ and $\mathrm{D})$.

Table 3 ALT Level in Each Group (u/l)

\begin{tabular}{|l|c|c|c|c|}
\hline Groups & $\mathbf{2 4 h}$ & $\mathbf{7 2 h}$ & $\mathbf{I 2 0 h}$ & $\mathbf{1 6 8 h}$ \\
\hline Control group & $22.37 \pm 2.66$ & $21.58 \pm 2.42$ & $21.55 \pm 4.34$ & $22.83 \pm 2.68$ \\
Low-dose group & $24.32 \pm 4.48^{*}$ & $25.95 \pm 0.87^{*}$ & $45.02 \pm 2.7 I^{* * \#}$ & $65.38 \pm 3.19^{* * \#}$ \\
Middle-dose group & $41.75 \pm 1.79^{* *}$ & $61.75 \pm 3.18^{* * \#}$ & $74.18 \pm 3.79 * * \#$ & $95.48 \pm 2.84^{* * \#}$ \\
High-dose group & $63.05 \pm 3.31^{* *}$ & $73.58 \pm 0.66^{* * \#}$ & $85.87 \pm 3.18^{* * \#}$ & - \\
\hline
\end{tabular}

Notes: Data are presented as mean \pm standard deviation; $* \mathrm{P}<0.05$ vs parallel control group; $* * \mathrm{P}<0.01$ vs parallel control group; ${ }^{\#}<<0.01$ vs $24 \mathrm{~h}$ in this group; -, no specimen collected.

Table 4 AST Level in Each Group (u/l)

\begin{tabular}{|l|c|c|c|c|}
\hline Groups & $\mathbf{2 4 h}$ & $\mathbf{7 2 h}$ & $\mathbf{1 2 0 h}$ & $\mathbf{1 6 8 h}$ \\
\hline Control group & $102.80 \pm 5.13$ & $91.33 \pm 6.88$ & $95.12 \pm 7.40$ & $101.98 \pm 4.34$ \\
Low-dose group & $113.82 \pm 8.78$ & $126.53 \pm 5.67 * * \#$ & $262.18 \pm 4.40^{* * \#}$ & $305.04 \pm 2.96 * * \#$ \\
Middle-dose group & $140.48 \pm 3.45^{* *}$ & $169.42 \pm 9.08^{* * \#}$ & $274.67 \pm 7.93 * * \#$ & $348.16 \pm 6.45 * * \#$ \\
High-dose group & $158.08 \pm 12.52^{* *}$ & $408.42 \pm 4.06 * * \#$ & $411.50 \pm 4.25 * * \#$ & - \\
\hline
\end{tabular}

Notes: Data are presented as mean \pm standard deviation; ${ }^{* * \mathrm{P}}<0.01$ vs parallel control group; ${ }^{*} \mathrm{p}<0.01$ vs $24 \mathrm{~h}$ in this group; - no specimen collected. 

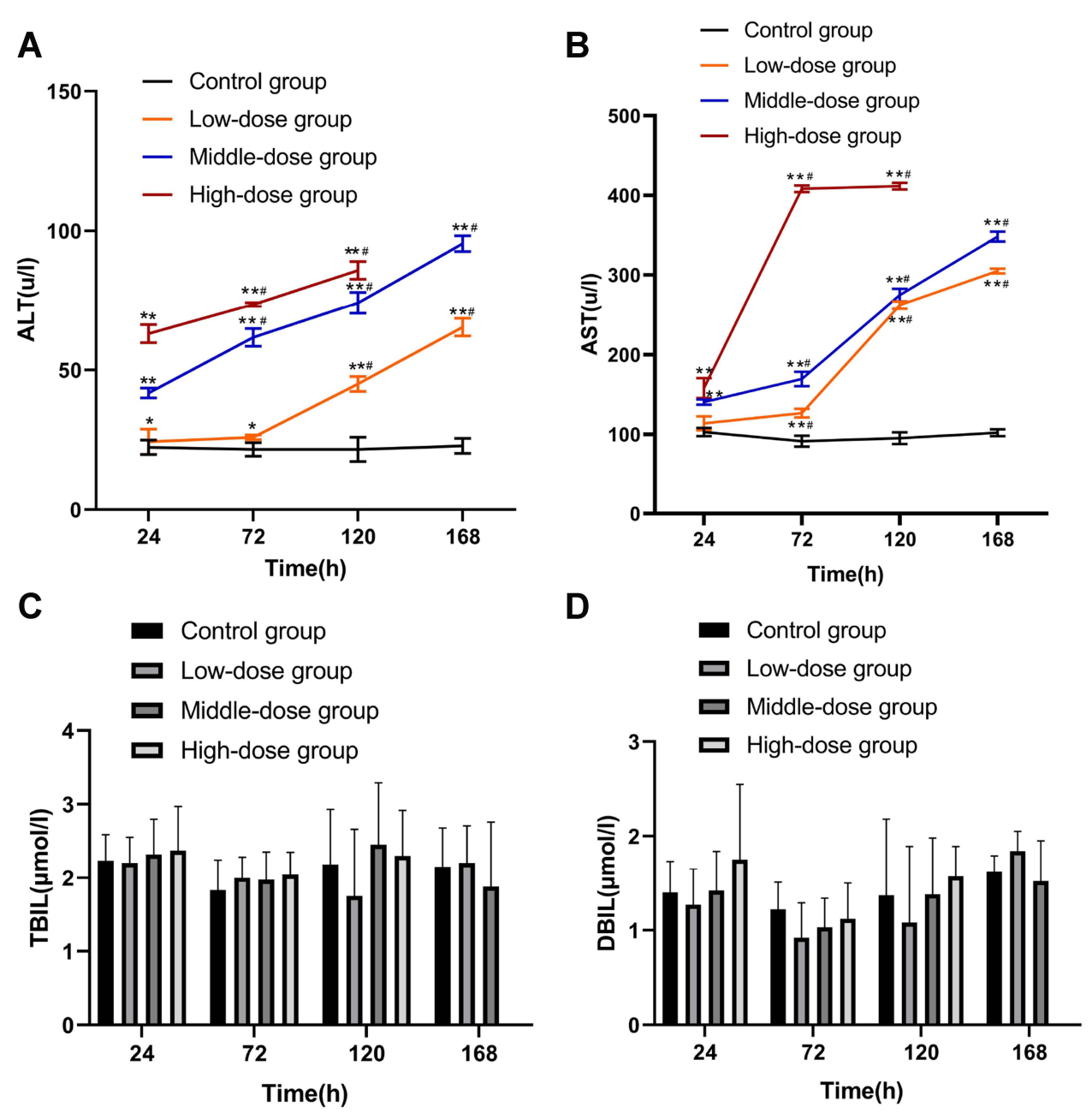

Figure 2 Effect of sodium cyclamate on serum levels of liver enzymes and bilirubin of mice. The serum levels of ALT (A), AST (B), TBIL (C) and DBIL (D) were measured sodium cyclamate-treated at $24 \mathrm{~h}, 72 \mathrm{~h}, 120 \mathrm{~h}$ and $168 \mathrm{~h}$. Values are the mean \pm standard deviation. $* \mathrm{P}<0.05$ vs parallel control group; ${ }^{* * P}<0.0 \mathrm{I}$ vs parallel control group; ${ }^{*} \mathrm{P}<$ 0.01 vs $24 \mathrm{~h}$ in this group. ALT, alanine aminotransferase; AST, aspartate aminotransferase; TBIL, total bilirubin; DBIL, direct bilirubin.

\section{Evaluation of Heart Injury by Serum Analysis}

The differences in the serum levels of CK, CK-MB and cTnT were determined among the 4 groups. Compared with the parallel control group, the serum levels of CK and CK-MB in the high-dose (12,000 $\mathrm{mg} / \mathrm{kg} / \mathrm{day}$, intraperitoneally) group at $24 \mathrm{~h}$ and the low-dose $(3000 \mathrm{mg} / \mathrm{kg} /$ day, intraperitoneally) group at $168 \mathrm{~h}$ were increased $(\mathrm{P}<0.05)$. The serum levels of CK and CK-MB in the high-dose $(12,000 \mathrm{mg} / \mathrm{kg} /$ day, intraperitoneally) group at $72 \mathrm{~h}$ and $120 \mathrm{~h}$ were increased significantly $(\mathrm{P}<0.01)$, also in the middle-dose $(6000 \mathrm{mg} / \mathrm{kg} / \mathrm{day}$, intraperitoneally) group at $168 \mathrm{~h}(\mathrm{P}<0.01)$. The serum level of cTnT in the high-dose $(12,000 \mathrm{mg} / \mathrm{kg} / \mathrm{day}$, intraperitoneally) group at $24 \mathrm{~h}$ was increased $(\mathrm{P}<0.05)$. The serum level of cTnT in the high-dose $(12,000 \mathrm{mg} / \mathrm{kg} /$ day, intraperitoneally) group at $72 \mathrm{~h}$ and $120 \mathrm{~h}$ were increased significantly

Table 5 TBIL Level in Each Group ( $\mu \mathrm{mol} / \mathrm{l})$

\begin{tabular}{|l|c|c|c|c|}
\hline Groups & $\mathbf{2 4 h}$ & $\mathbf{7 2 h}$ & I 20h & I68h \\
\hline Control group & $2.23 \pm 0.36$ & $1.83 \pm 0.41$ & $2.18 \pm 0.75$ & $2.15 \pm 0.53$ \\
Low-dose group & $2.20 \pm 0.35$ & $2.00 \pm 0.28$ & $1.75 \pm 0.91$ & $2.20 \pm 0.51$ \\
Middle-dose group & $2.32 \pm 0.48$ & $1.97 \pm 0.38$ & $2.45 \pm 0.84$ & $1.88 \pm 0.88$ \\
High-dose group & $2.37 \pm 0.60$ & $2.05 \pm 0.30$ & $2.30 \pm 0.62$ & - \\
\hline
\end{tabular}

Notes: Data are presented as mean \pm standard deviation; - , no specimen collected. 
Table 6 DBIL Level in Each Group $(\mu \mathrm{mol} / \mathrm{l})$

\begin{tabular}{|l|c|c|c|c|}
\hline Groups & $\mathbf{2 4 h}$ & $\mathbf{7 2 h}$ & $\mathbf{1 2 0 h}$ & $\mathbf{1 6 8 h}$ \\
\hline Control group & $1.40 \pm 0.33$ & $1.22 \pm 0.29$ & $1.37 \pm 0.81$ & $1.62 \pm 0.17$ \\
Low-dose group & $1.27 \pm 0.38$ & $0.92 \pm 0.37$ & $1.08 \pm 0.81$ & $1.84 \pm 0.21$ \\
Middle-dose group & $1.42 \pm 0.42$ & $1.03 \pm 0.31$ & $1.38 \pm 0.60$ & $1.52 \pm 0.43$ \\
High-dose group & $1.75 \pm 0.80$ & $1.12 \pm 0.38$ & $1.57 \pm 0.32$ & - \\
\hline
\end{tabular}

Notes: Data are presented as mean \pm standard deviation; - , no specimen collected.

( $\mathrm{P}<0.01)$, also in the low-dose $(3000 \mathrm{mg} / \mathrm{kg} / \mathrm{day}$, intraperitoneally) and the middle-dose $(6000 \mathrm{mg} / \mathrm{kg} / \mathrm{day}$, intraperitoneally) groups at $168 \mathrm{~h}(\mathrm{P}<0.01)$. Compared with $24 \mathrm{~h}$ in each group, the serum levels of CK, CK-MB and cTnT in the low-dose $(3000 \mathrm{mg} / \mathrm{kg} / \mathrm{day}$, intraperitoneally) and the middle-dose $(6000 \mathrm{mg} / \mathrm{kg} /$ day, intraperitoneally) groups at $168 \mathrm{~h}$ were increased significantly $(\mathrm{P}<0.01)$, also in the high-dose $(12,000 \mathrm{mg} / \mathrm{kg} /$ day, intraperitoneally) group at $72 \mathrm{~h}$ and $120 \mathrm{~h}$ $(\mathrm{P}<0.01)$. There were no significant difference in the serum levels of CK, CK-MB and cTnT among the control groups $(\mathrm{P}>0.05$; Tables 7- Table 9 and Figure 3).

Table 7 CK Level in Each Group (u/l)

\begin{tabular}{|l|c|c|c|c|}
\hline Groups & $\mathbf{2 4 h}$ & $\mathbf{7 2 h}$ & $\mathbf{1 2 0 h}$ & $\mathbf{1 6 8 h}$ \\
\hline Control group & $1271.50 \pm 18.19$ & $1228.83 \pm 73.92$ & $1220.33 \pm 92.55$ & $1256.67 \pm 95.27$ \\
Low-dose group & $1277.17 \pm 49.46$ & $1232.50 \pm 59.06$ & $1265.50 \pm 76.11$ & $1386.80 \pm 28.2$ *\#\# $^{-11}$ \\
Middle-dose group & $1288.67 \pm 56.23$ & $1240.17 \pm 87.52$ & $1352.50 \pm 33.33$ & $3130.60 \pm 75.63 * * \#$ \\
High-dose group & $1326.17 \pm 38.03^{*}$ & $2793.17 \pm 36.27 * * \#$ & $4062.00 \pm 49.79 * * \#$ & - \\
\hline
\end{tabular}

Notes: Data are presented as mean \pm standard deviation; ${ }^{*} \mathrm{P}<0.05$ vs parallel control group; ${ }^{*} \mathrm{P}<0.0 \mathrm{l}$ vs parallel control group; ${ }^{\#} \mathrm{p}<0.0 \mathrm{l}$ vs $24 \mathrm{~h}$ in this group; - , no specimen collected.

Table 8 CK-MB Level in Each Group (u/l)

\begin{tabular}{|l|c|c|c|c|}
\hline Groups & $\mathbf{2 4 h}$ & $\mathbf{7 2 h}$ & $\mathbf{1 2 0 h}$ & $\mathbf{1 6 8 h}$ \\
\hline Control group & $654.50 \pm 53.73$ & $671.00 \pm 38.99$ & $685.50 \pm 40.29$ & $701.50 \pm 25.08$ \\
Low-dose group & $663.67 \pm 36.78$ & $677.00 \pm 39.98$ & $698.83 \pm 53.31$ & $769.40 \pm 49.8$ * $^{*}$ \\
Middle-dose group & $680.83 \pm 46.90$ & $684.67 \pm 58.31$ & $735.67 \pm 49.31$ & $855.20 \pm 38.22^{* * \#}$ \\
High-dose group & $725.00 \pm 40.37^{*}$ & $1094.83 \pm 60.36 * * \#$ & $1270.67 \pm 26.08^{* * \#}$ & - \\
\hline
\end{tabular}

Notes: Data are presented as mean \pm standard deviation; $* \mathrm{P}<0.05$ vs parallel control group; $* * \mathrm{P}<0.0 \mathrm{l}$ vs parallel control group; ${ }^{*} \mathrm{P}<0.0 \mathrm{I}$ vs $24 \mathrm{~h}$ in this group; - no specimen collected.

Table 9 cTnT Level in Each Group $(\mu \mathrm{g} / \mathrm{l})$

\begin{tabular}{|l|c|c|c|c|}
\hline Groups & $\mathbf{2 4 h}$ & $\mathbf{7 2 h}$ & $\mathbf{I 2 0 h}$ & $\mathbf{1 6 8 h}$ \\
\hline Control group & $29.40 \pm 4.48$ & $29.91 \pm 3.98$ & $29.26 \pm 5.69$ & $30.58 \pm 5.00$ \\
Low-dose group & $30.00 \pm 5.07$ & $29.99 \pm 5.25$ & $33.68 \pm 3.20$ & $74.53 \pm 3.88^{* * \#}$ \\
Middle-dose group & $30.06 \pm 5.42$ & $30.58 \pm 5.28$ & $37.36 \pm 2.75$ & $95.12 \pm 3.69 * * \#$ \\
High-dose group & $36.54 \pm 1.40^{*}$ & $62.29 \pm 2.56 * * \#$ & $84.86 \pm 2.14^{* * \#}$ & - \\
\hline
\end{tabular}

Notes: Data are presented as mean \pm standard deviation; ${ }^{*} \mathrm{P}<0.05$ vs parallel control group; $* * \mathrm{P}<0.0 \mathrm{I}$ vs parallel control group; ${ }^{*} \mathrm{P}<0.0 \mathrm{I}$ vs $24 \mathrm{~h}$ in this group; -, no specimen collected. 

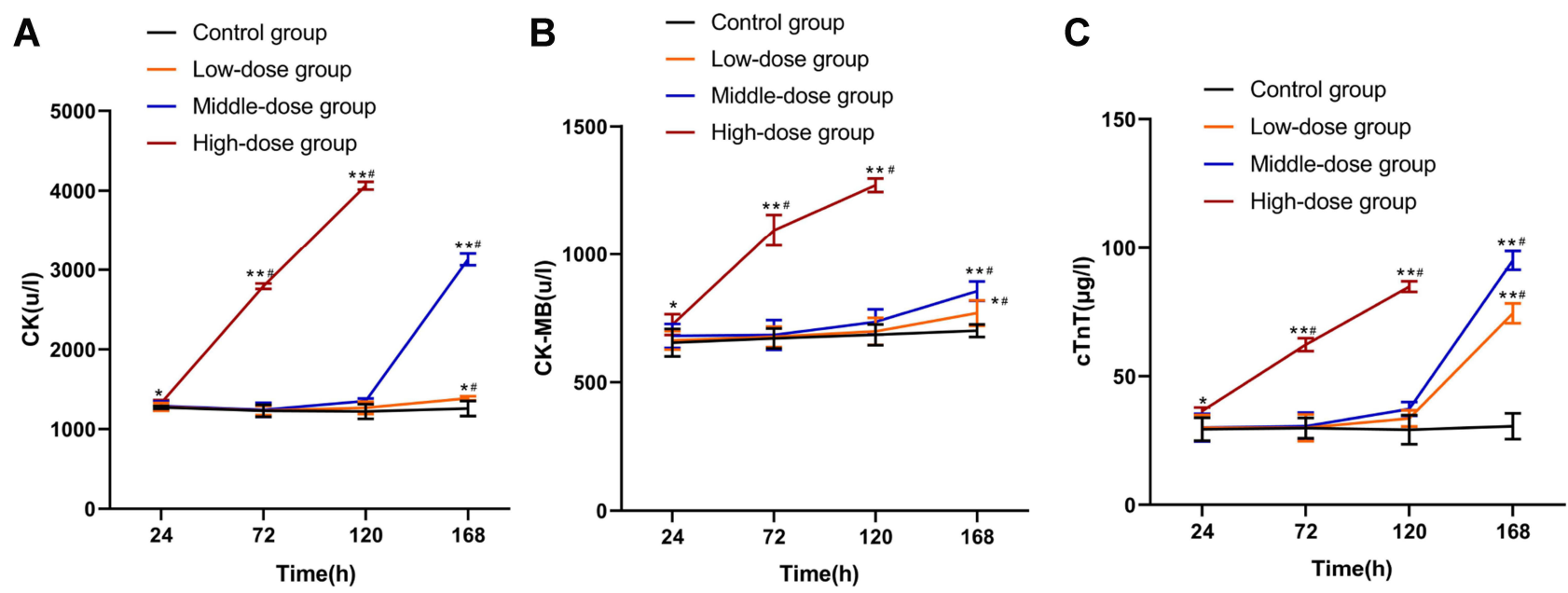

Figure 3 Effect of sodium cyclamate on serum levels of heart enzymes and cardiac troponin of mice. The serum levels of CK (A), CK-MB (B) and cTnT (C) were measured

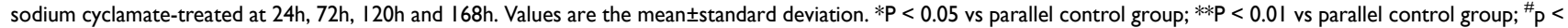
0.01 vs $24 \mathrm{~h}$ in this group. CK, creatine kinase; CK-MB, creatine kinase-MB; cTnT, cardiac troponin T.

\section{Evaluation of Kidney Injury by Serum Analysis}

No correlation was found between the serum levels of SCr and BUN with the sodium cyclamate dosage and treated time in this experimental period. Compared with the parallel control group and $24 \mathrm{~h}$ in each group, there were no significant difference between the serum levels of SCr and BUN in each group $(\mathrm{P}>0.05$; Tables 10 and 11 and Figure 4).

\section{Pathological Changes in Liver}

As shown in Figure 5, clear structures of hepatic lobules and hepatic cords were observed in the control group with large and round nuclei in the center of the cells, which arranged orderly. However, in the low-dose (3000 $\mathrm{mg} / \mathrm{kg} /$ day, intraperitoneally) group, the arrangement of hepatocytes was slightly disordered, some hepatocytes edema and ballooning changes. In the middle-dose $(6000 \mathrm{mg} / \mathrm{kg} /$ day, intraperitoneally) group, the arrangement of liver cells was disordered, lots of hepatocytes edema and ballooning changes, a small amount of inflammatory cells infiltrated, the chromatin in nucleus reduced obviously. Until $120 \mathrm{~h}$, the cytoplasm was reduced, even loose into a reticular. In the high-dose (12,000 $\mathrm{mg} / \mathrm{kg} /$ day, intraperitoneally)

Table 10 SCr Level in Each Group $(\mu \mathrm{mol} / \mathrm{l})$

\begin{tabular}{|l|c|c|c|c|}
\hline Groups & $\mathbf{2 4 h}$ & $\mathbf{7 2 h}$ & $\mathbf{I 2 0 h}$ & $\mathbf{I 6 8 h}$ \\
\hline Control group & $21.17 \pm 5.00$ & $18.83 \pm 5.12$ & $19.67 \pm 2.8 \mathrm{I}$ & $25.67 \pm 3.50$ \\
Low-dose group & $20.50 \pm 3.62$ & $19.67 \pm 2.58$ & $18.83 \pm 4.96$ & $23.20 \pm 2.59$ \\
Middle-dose group & $22.33 \pm 3.56$ & $22.00 \pm 2.37$ & $23.83 \pm 4.54$ & $26.20 \pm 6.26$ \\
High-dose group & $21.50 \pm 3.02$ & $21.33 \pm 3.20$ & $22.67 \pm 2.52$ & - \\
\hline
\end{tabular}

Notes: Data are presented as mean \pm standard deviation; - , no specimen collected.

Table I I BUN Level in Each Group (Mmol/l)

\begin{tabular}{|l|c|c|c|c|}
\hline Groups & $\mathbf{2 4 h}$ & $\mathbf{7 2 h}$ & $\mathbf{1 2 0 h}$ & 168h \\
\hline Control group & $7.63 \pm 1.37$ & $8.65 \pm 1.67$ & $10.33 \pm 3.62$ & $9.88 \pm 3.32$ \\
Low-dose group & $7.72 \pm 1.98$ & $8.25 \pm 1.92$ & $7.95 \pm 2.70$ & $8.34 \pm 2.69$ \\
Middle-dose group & $7.62 \pm 0.75$ & $9.43 \pm 1.22$ & $8.18 \pm 0.86$ & $10.82 \pm 2.36$ \\
High-dose group & $7.43 \pm 0.94$ & $8.30 \pm 1.01$ & $8.73 \pm 1.55$ & - \\
\hline
\end{tabular}

Notes: Data are presented as mean \pm standard deviation; - , no specimen collected. 

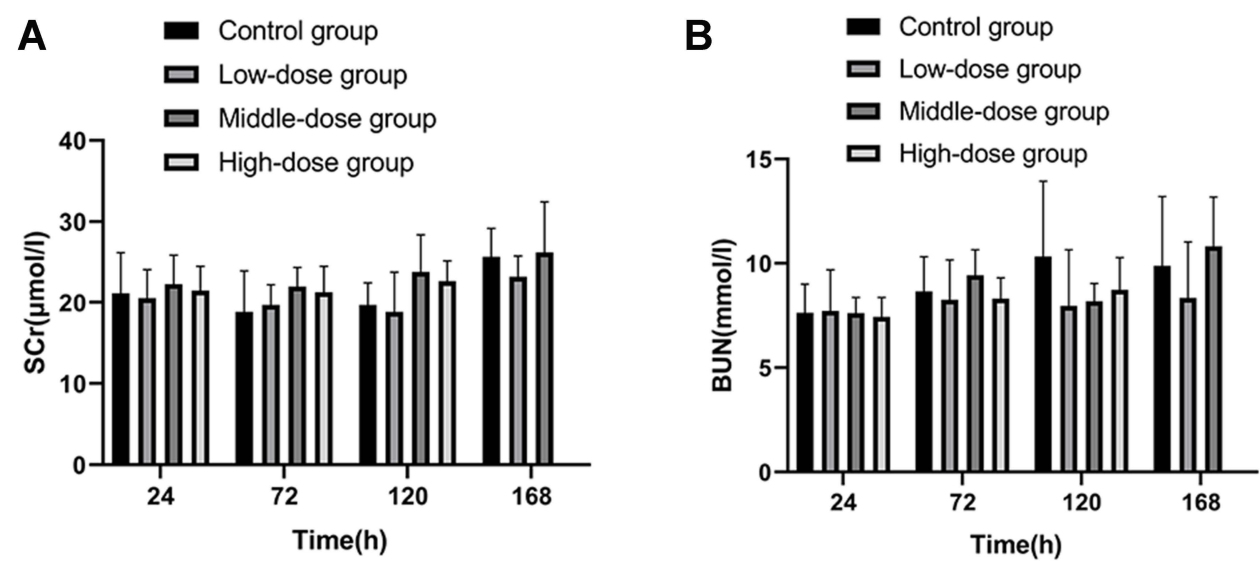

Figure 4 Effect of sodium cyclamate on serum levels of creatinine and blood urea nitrogen of mice. The serum levels of SCr (A) and BUN (B) were measured sodium cyclamate-treated at $24 \mathrm{~h}, 72 \mathrm{~h}, 120 \mathrm{~h}$ and $168 \mathrm{~h}$. Values are the mean \pm standard deviation. SCr, serum creatinine; BUN, blood urea nitrogen.

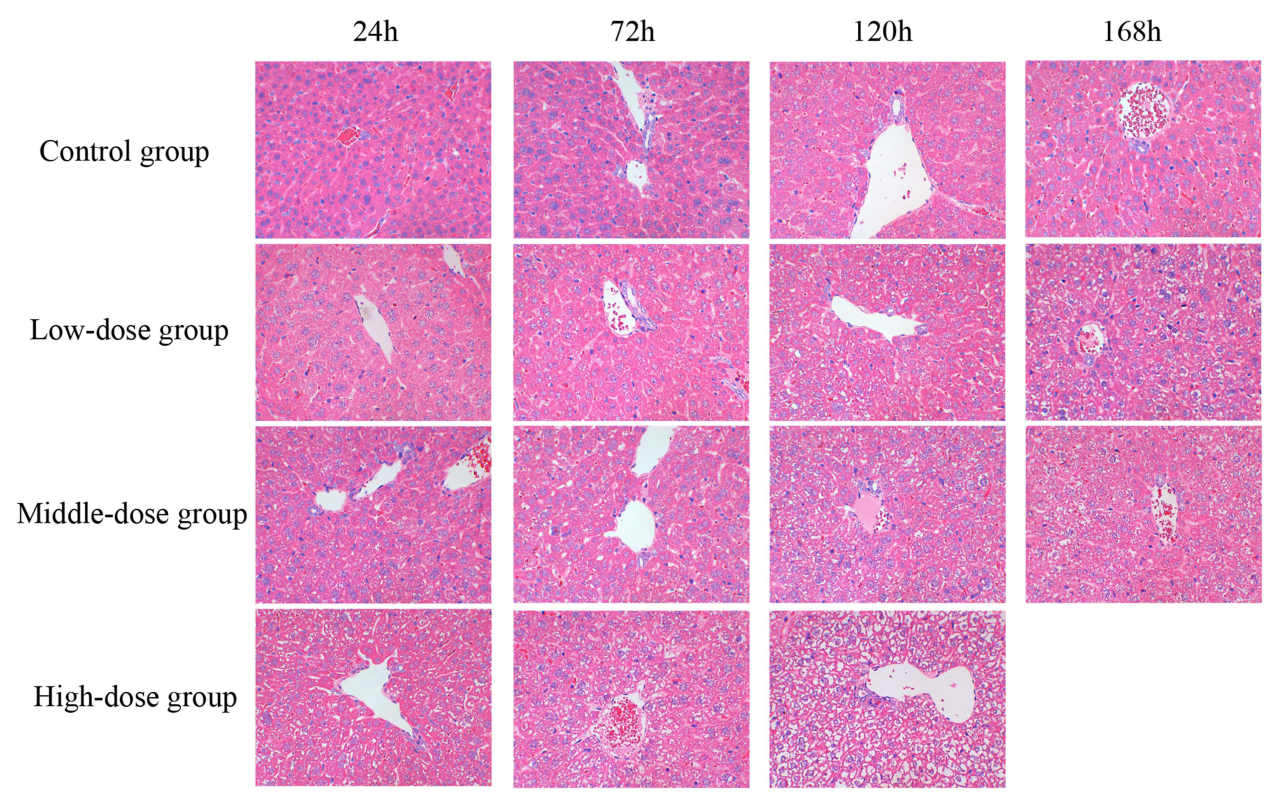

Figure 5 Sodium cyclamate induced liver injury. The liver sections were stained with HE and examined (magnification $\times 400)$. HE, hematoxylin and eosin.

group, the structure of hepatic lobules was destroyed, the arrangement of hepatic cords obviously disordered, a large number of hepatocytes edema and ballooning changes, inflammatory cells infiltrated, the proliferation and hypertrophy of Kupffer cells, scattered punctate necrosis and focal necrosis. These results demonstrated that sodium cyclamate caused liver damage, and with the increase of sodium cyclamate dosage and treated time, liver damage aggravated gradually.

\section{Pathological Changes in Heart}

As shown in Figure 6, cardiomyocytes were stained evenly and arranged neatly with clear structures in the control group. However, in the low-dose (3000 mg/kg/day, intraperitoneally) and the middle-dose $(6000 \mathrm{mg} / \mathrm{kg} /$ day, intraperitoneally) groups at $24 \mathrm{~h}, 72 \mathrm{~h}, 120 \mathrm{~h}$, a small amount of granular degeneration and ballooning changes appeared in individual muscle fibers gradually. In the high-dose $(12,000 \mathrm{mg} / \mathrm{kg} /$ day, intraperitoneally) group at $24 \mathrm{~h}, 72 \mathrm{~h}, 120 \mathrm{~h}$, the low-dose $(3000 \mathrm{mg} / \mathrm{kg} / \mathrm{day}$, intraperitoneally) and the middle-dose $(6000 \mathrm{mg} / \mathrm{kg} /$ day, intraperitoneally) groups at $168 \mathrm{~h}$, the whole myocardial bundle showed granular degeneration and ballooning changes, and some mycoplasma had vacuoles of varying sizes. These results revealed that myocardial injury began to appear after sodium cyclamate reached a measure of sodium cyclamate dosage and treated time. 


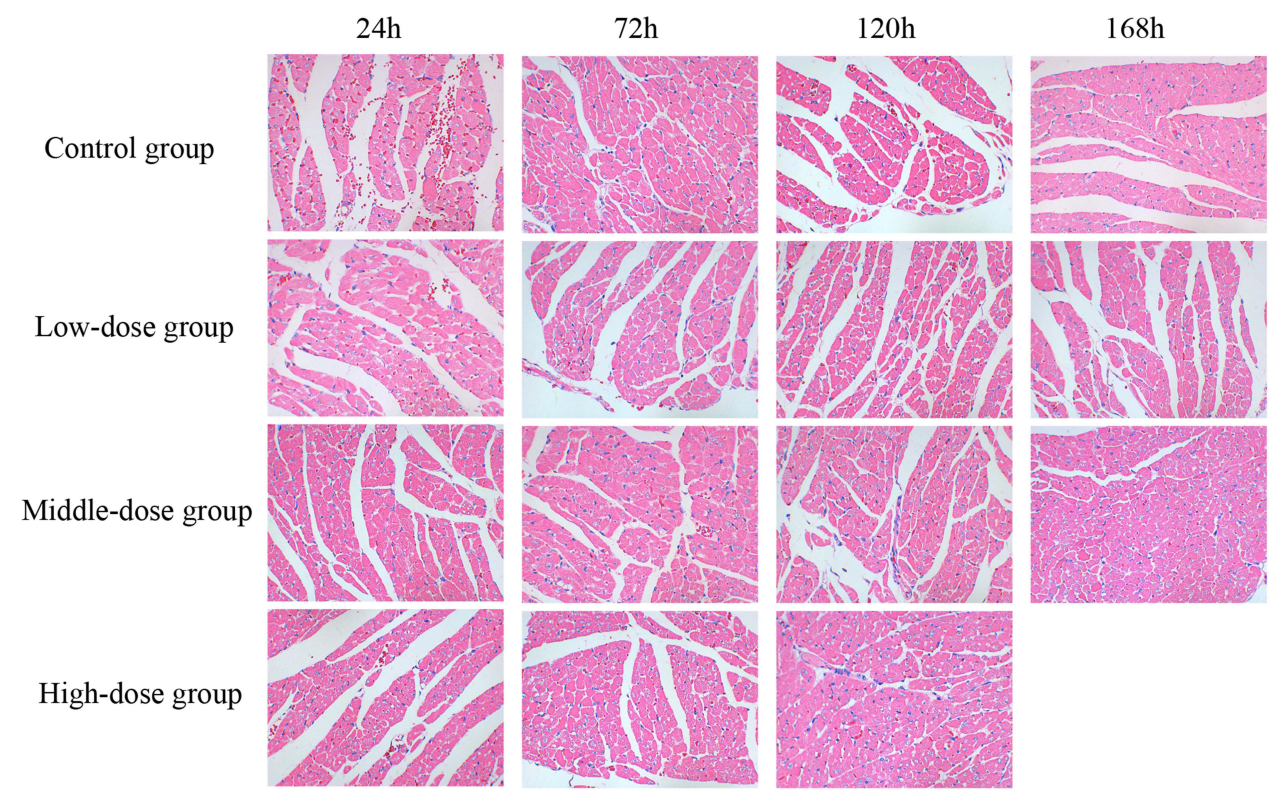

Figure 6 Sodium cyclamate induced heart injury. The heart sections were stained with HE and examined (magnification $\times 400)$. HE, hematoxylin and eosin.

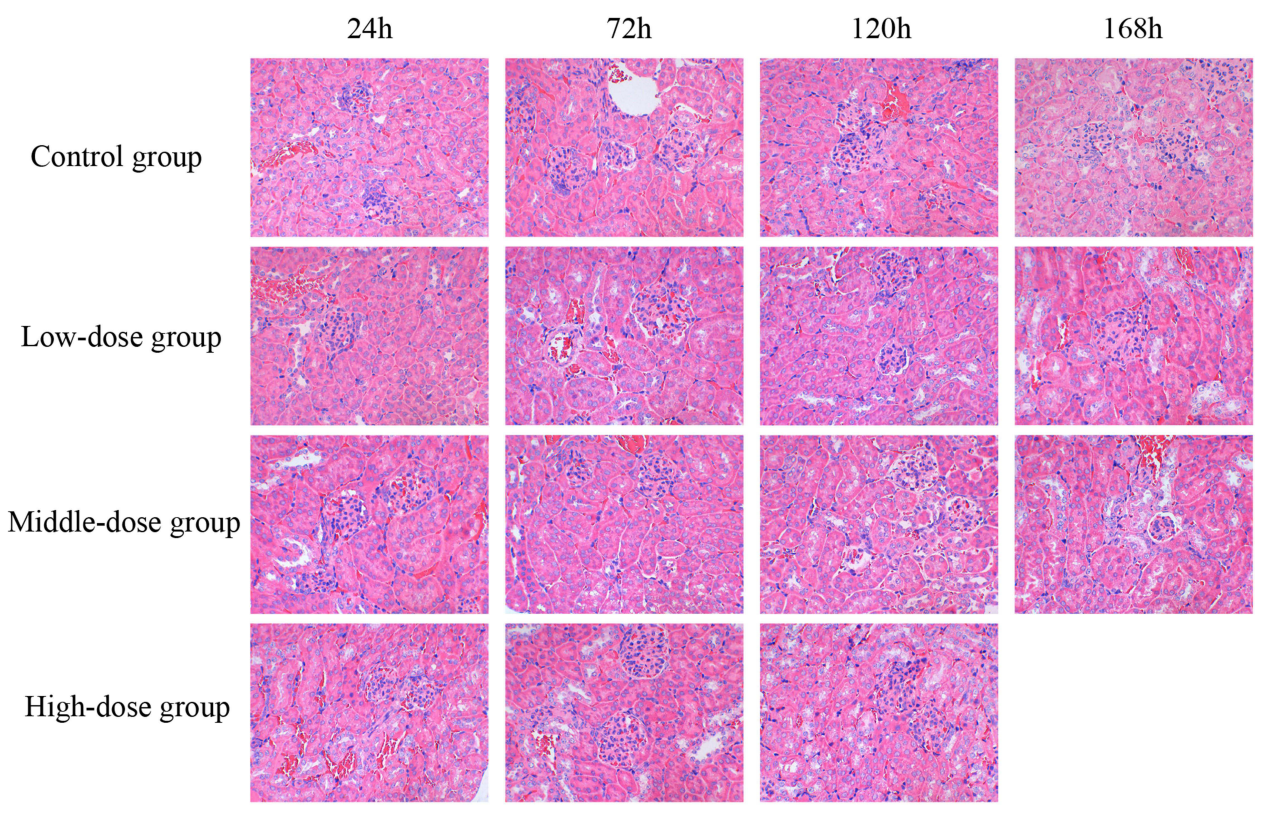

Figure 7 Sodium cyclamate induced kidney injury. The kidney sections were stained with HE and examined (magnification $\times 400)$. HE, hematoxylin and eosin.

\section{Pathological Changes in Kidney}

As shown in Figure 7, the structures of renal tubules and glomerulus were normal in the control group. In the low-dose (3000 mg/kg/day, intraperitoneally) and the middle-dose $(6000 \mathrm{mg} / \mathrm{kg} /$ day, intraperitoneally) groups at $120 \mathrm{~h}$, individual renal tubules were dilated, also in the high-dose $(12,000 \mathrm{mg} / \mathrm{kg} /$ day, intraperitoneally) group at $24 \mathrm{~h}$. However, with the increase of sodium cyclamate dosage and treated time, the epithelial cells of the renal tubules showed different degrees of brush edge falling off and necrosis. Some of the basement membranes of the renal tubules were exposed and inflammatory cells infiltrated in the low-dose $(3000 \mathrm{mg} / \mathrm{kg} / \mathrm{day}$, intraperitoneally) and the middle-dose $(6000 \mathrm{mg} / \mathrm{kg} /$ day, intraperitoneally) groups at $168 \mathrm{~h}$, the high-dose $(12,000 \mathrm{mg} / \mathrm{kg} /$ day, intraperitoneally) group at $72 \mathrm{~h}$ and $120 \mathrm{~h}$. These results reported that kidney injury began to appear after sodium cyclamate reached a measure of sodium cyclamate 
dosage and treated time. Moreover, the kidney damage caused by sodium cyclamate is mainly in renal tubular structure, not in glomerulus.

\section{Transmission Electron Microscopy}

According to the changes of serum marker levels in liver, heart, kidney and HE staining in these tissues, it was preliminarily found that the liver damage was obvious in the middle-dose $(6000 \mathrm{mg} / \mathrm{kg} / \mathrm{day}$, intraperitoneally) group at $120 \mathrm{~h}$, while no obvious in the heart and kidney. Therefore, the liver tissues in the middle-dose $(6000 \mathrm{mg} / \mathrm{kg} / \mathrm{day}$, intraperitoneally) group at $120 \mathrm{~h}$ was compared with the control group by transmission electron microscopy.

The ultra structural examination of the liver sections of the control group exhibited a round nucleus with homogeneous chromatin in hepatocytes, prominent nuclear membrane, abundant glycogen granules, round or oval mitochondria, and normal rough endoplasmic reticulum (Figure $8 \mathrm{~A}$ and $\mathrm{B}$ ). The ultra structural examination of the liver sections of the middle-dose $(6000 \mathrm{mg} / \mathrm{kg} / \mathrm{day}$, intraperitoneally) group at $120 \mathrm{~h}$, irregular chromatin condensation presented in the nuclei. In hepatocytes, the number of mitochondria decreased, the cristae structure became disordered, shortened or disappeared, the number of glycogen decreased significantly and the rough endoplasmic reticulum broke (Figure 8C and D). These results indicated that the sodium cyclamate-induced acute DILI mouse model could be established by intraperitoneal injection of $6000 \mathrm{mg} / \mathrm{kg} / \mathrm{day}$ sodium cyclamate for 5 days successfully.

\section{A}

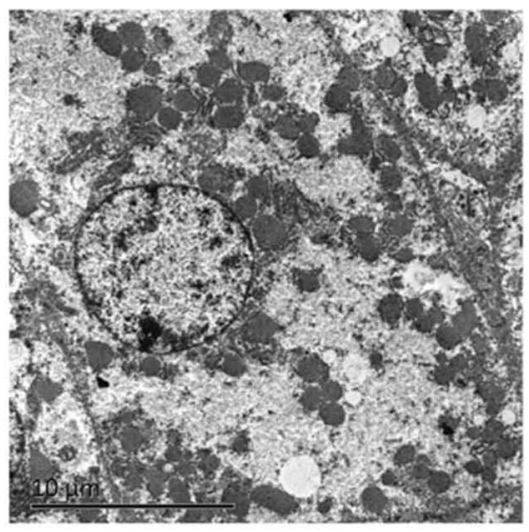

C

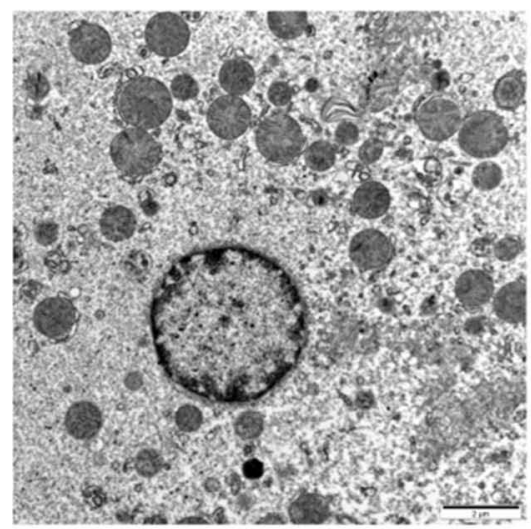

B

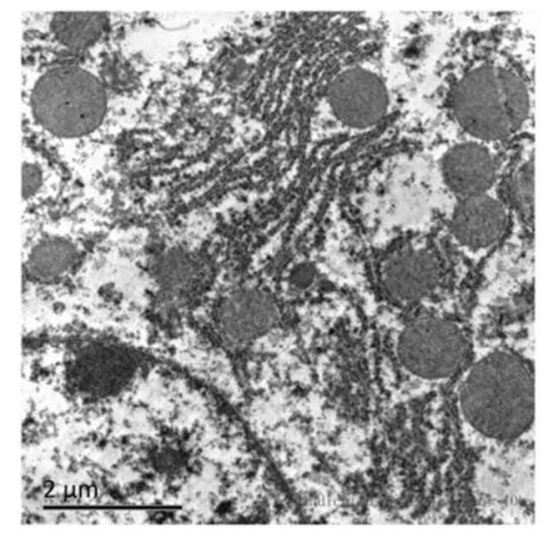

D

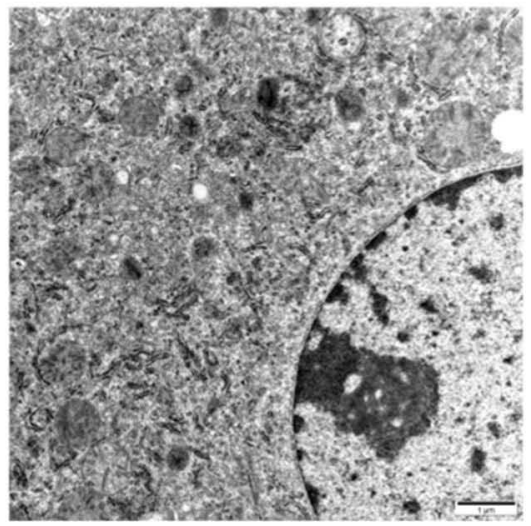

Figure 8 Sodium cyclamate induced liver injury by intraperitoneal injection of $6000 \mathrm{mg} / \mathrm{kg} /$ day for 5 days successfully. It was evidenced by transmission electron microscopy micrographs of the hepatocytes of the liver tissue in the control (A and B) and sodium cyclamate-treated at I20h (C and D) groups. (scale bars: (A) I0 $\mu \mathrm{m}$; B, (C) $2 \mu \mathrm{m}$; (D) $\mathrm{I} \mu \mathrm{m})$. 


\section{Immunohistochemical Expression of TNF- $\alpha$ and IL-I $\beta$}

The positive expression color was tan. In the control group, negative immunostaining reaction of TNF- $\alpha$ and IL-1 $\beta$ protein were observed in most of liver, heart and kidney tissues. In the sodium cyclamate-treated groups, the range of positive expression increased with the increase of sodium cyclamate dosage.

At $120 \mathrm{~h}$, the average optical density (IOD/Area) of TNF- $\alpha$ and IL-1 $\beta$ positive expression increased in the liver tissues with the increase of the dosage. Compared with the control group, the IOD/Area of TNF- $\alpha$ and IL-1 $\beta$ positive expression in the low-dose $(3000 \mathrm{mg} / \mathrm{kg} /$ day, intraperitoneally) group were increased significantly $(\mathrm{P}<0.05)$, also in the middle-dose $(6000 \mathrm{mg} / \mathrm{kg} / \mathrm{day}$, intraperitoneally) and the high-dose $(12,000 \mathrm{mg} / \mathrm{kg} / \mathrm{day}$, intraperitoneally) groups $(\mathrm{P}<0.01$; Table 12 , Figures $9 \mathrm{~A}$ and 10).

In the heart tissues, compared with the control group, the IOD/Area of TNF- $\alpha$ and IL-1 $\beta$ positive expression in the low-dose $(3000 \mathrm{mg} / \mathrm{kg} /$ day, intraperitoneally) and the middle-dose $(6000 \mathrm{mg} / \mathrm{kg} / \mathrm{day}$, intraperitoneally) groups were not significant difference $(\mathrm{P}>0.05)$, while in the high-dose $(12,000 \mathrm{mg} / \mathrm{kg} / \mathrm{day}$, intraperitoneally) group increased significantly $(\mathrm{P}<0.05$; Table 13, Figures $9 \mathrm{~B}$ and 11).

In the kidney tissues, compared with the control group, the IOD/Area of TNF- $\alpha$ positive expression in the low-dose $(3000 \mathrm{mg} / \mathrm{kg} /$ day, intraperitoneally) and the middle-dose $(6000 \mathrm{mg} / \mathrm{kg} /$ day, intraperitoneally) groups were not significant difference $(\mathrm{P}>0.05)$, while in the high-dose $(12,000 \mathrm{mg} / \mathrm{kg} / \mathrm{day}$, intraperitoneally) group increased significantly $(\mathrm{P}<$ $0.05)$; the IOD/Area of IL-1 $\beta$ positive expression in the low-dose $(3000 \mathrm{mg} / \mathrm{kg} / \mathrm{day}$, intraperitoneally) group was not significant difference $(\mathrm{P}>0.05)$, while in the middle-dose $(6000 \mathrm{mg} / \mathrm{kg} /$ day, intraperitoneally) group $(\mathrm{P}<0.05)$ and the high-dose $(12,000 \mathrm{mg} / \mathrm{kg} /$ day, intraperitoneally) group increased significantly $(\mathrm{P}<0.01$; Table 14 , Figures $9 \mathrm{C}$ and 12$)$.

These results manifested that the pathogenesis of acute liver, heart and kidney injury induced by sodium cyclamate closely related to the inflammatory response mediated by TNF- $\alpha$ and IL-1 $\beta$.

\section{Discussion}

In the past research, the inducers commonly used to establish the acute DILI animal model include $\mathrm{CCl}_{4}$, dimethylnitrosamine (DMN), D-galactosamine combined with lipopolysaccharide and acetaminophen (APAP) ${ }^{18}$ But most of them had their shortcomings. $\mathrm{CCl}_{4}$ has strong toxicity, ${ }^{19}$ which caused damage to multiple organ functions. It is volatile, which caused irritation symptoms to the operator's eyes and upper respiratory tract. DMN also had highly toxic, ${ }^{20}$ easily absorbed by the operator through the respiratory tract, digestive tract and skin, which may caused the operator headache, abdominal pain, nausea and dizziness. In severe cases, it may caused death. The operator should be careful when operating. Moreover, its excreta is still toxic within $24 \mathrm{~h}$, which polluted the surrounding environment and other people. D-galactosamine combined with lipopolysaccharide only damaged to liver, ${ }^{21}$ but its price is expensive. The solubility of APAP is poor, which limited the success rate of its modeling. ${ }^{22}$ Therefore, it is worth establishing a new drug or chemical induced liver injury animal model, which is simple to operate, safety for operators, high specificity, inexpensive and stable.

As a common food additive, sodium cyclamate is used in preserved fruits, jams, pastries, biscuits and bread. ${ }^{23,24}$ It has clear regulations on the dosage and use scope in China. However, in recent years, some illegal businesses have seriously exceeded the scope and limit in the use of sodium cyclamate in order to gain more benefits. Previous studies

Table 12 The Expression of TNF- $\alpha$ and IL-I $\beta$ Protein in the Liver at I20h (IOD/Area)

\begin{tabular}{|l|c|c|}
\hline Groups & TNF- $\alpha$ & IL-I $\beta$ \\
\hline Control group & $0.0151 \pm 0.0010$ & $0.0184 \pm 0.0008$ \\
Low-dose group & $0.0164 \pm 0.001 I^{*}$ & $0.0198 \pm 0.0010^{*}$ \\
Middle-dose group & $0.0210 \pm 0.0008^{* *}$ & $0.0275 \pm 0.001 I^{* *}$ \\
High-dose group & $0.0244 \pm 0.0009 * *$ & $0.0333 \pm 0.0008^{* *}$ \\
\hline
\end{tabular}

Notes: Data are presented as mean \pm standard deviation; $* \mathrm{P}<0.05$ vs control group; $* * \mathrm{P}<0.01$ vs control group. 

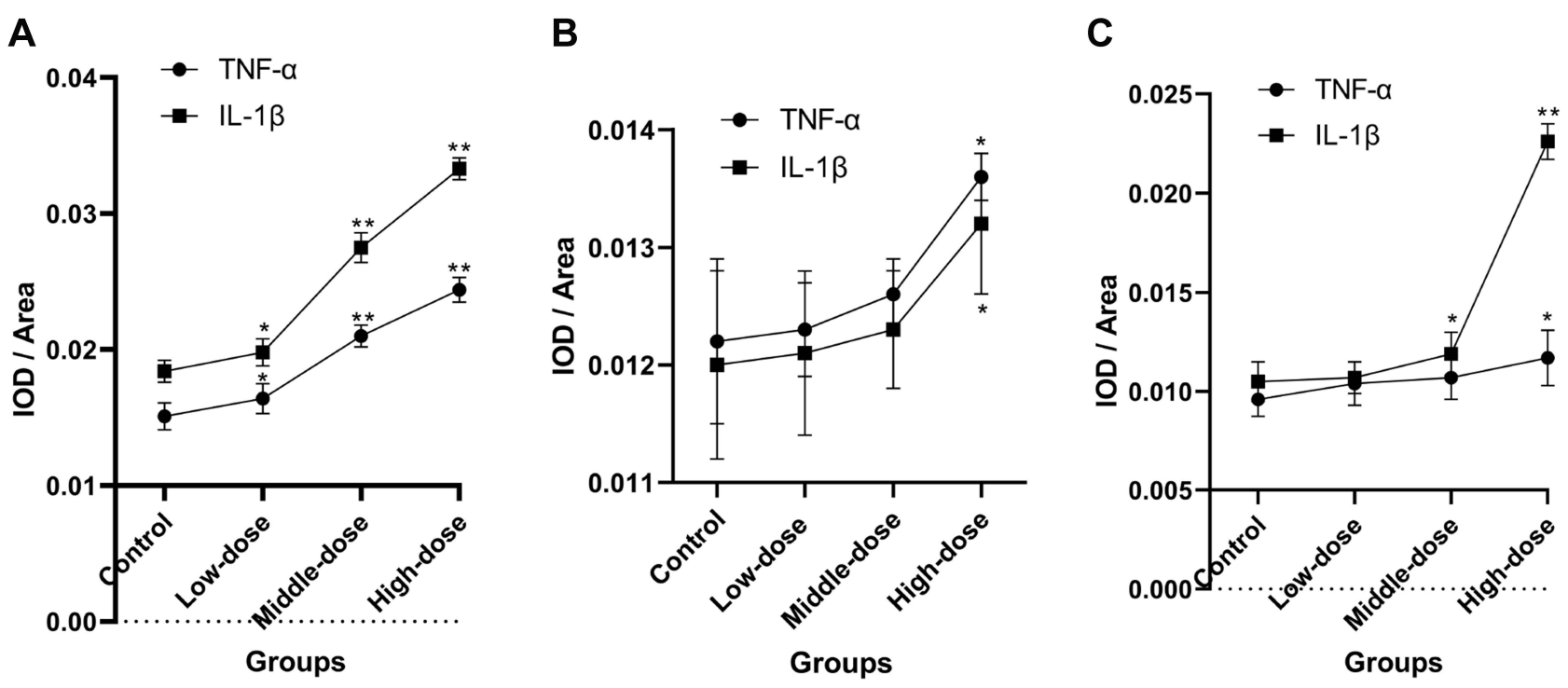

Figure 9 The IOD/Area value of TNF- $\alpha$ and IL-I $\beta$ positive expression in the liver $(\mathbf{A})$, heart $(\mathbf{B})$ and kidney $(\mathbf{C})$ tissues positive expression in each group. The IOD/Area were measured at $120 \mathrm{~h}$. Values are the mean \pm standard deviation. $* \mathrm{P}<0.05$ vs control group; $* * \mathrm{P}<0.0 \mathrm{I}$ vs control group. IOD/Area, average optical density.

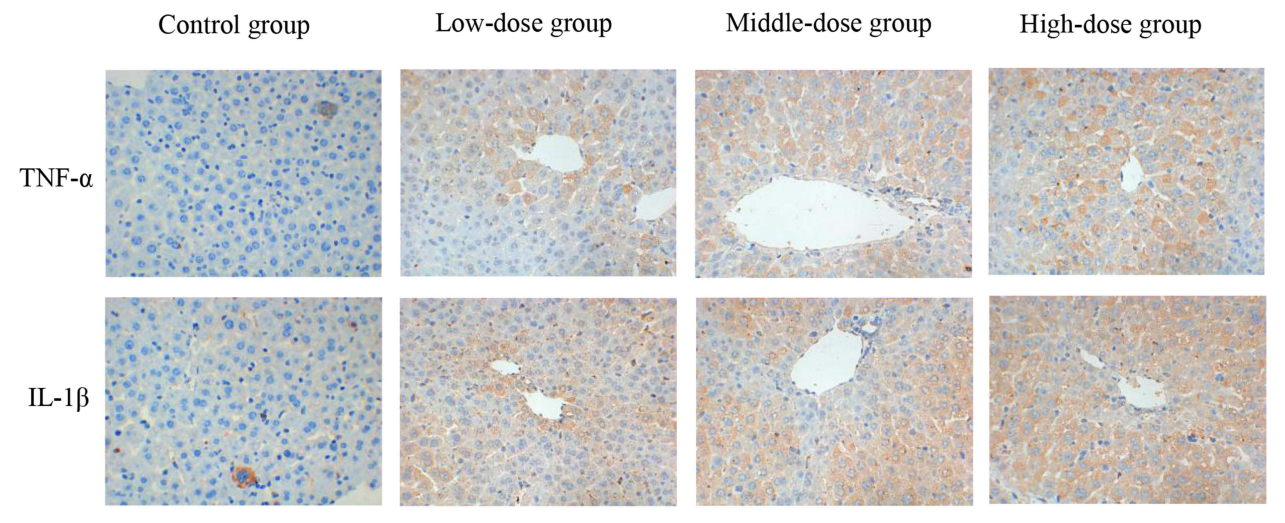

Figure 10 Expression of TNF- $\alpha$ and IL-I $\beta$ detected via immunohistochemistry in the liver sections at I20h (magnification $\times 400$ ). The positive color was tan.

have shown that sodium cyclamate can widely distributed in the liver, heart, kidney and gastrointestinal tract. ${ }^{7,25}$ After being absorbed in the body, it may caused liver cell necrosis, myocardial calcification, nephrocalcinosis and diarrhea. It can pass through the placental barrier, and even lead to the bladder cancer. ${ }^{26}$

Sodium cyclamate had great solubility, which is non hygroscopic in solid state and not support the growth of bacteria. It is easy to preserve, readily available, inexpensive, no stimulation and toxicity to skin, respiratory tract and digestive tract during operation. The animal commonly used in experiment included mouse, rat, pig, monkey, rabbit and dog.

Table 13 The Expression of TNF- $\alpha$ and IL-I $\beta$ Protein in the Heart at I20h (IOD/Area)

\begin{tabular}{|l|c|c|}
\hline Groups & TNF- $\alpha$ & IL-I $\boldsymbol{\beta}$ \\
\hline Control group & $0.0122 \pm 0.0007$ & $0.0120 \pm 0.0008$ \\
Low dose group & $0.0123 \pm 0.0004$ & $0.0121 \pm 0.0007$ \\
Middle dose group & $0.0126 \pm 0.0003$ & $0.0123 \pm 0.0005$ \\
High dose group & $0.0136 \pm 0.0002^{*}$ & $0.0132 \pm 0.0006^{*}$ \\
\hline
\end{tabular}

Notes: Data are presented as mean \pm standard deviation; *P $<0.05$ vs control group. 


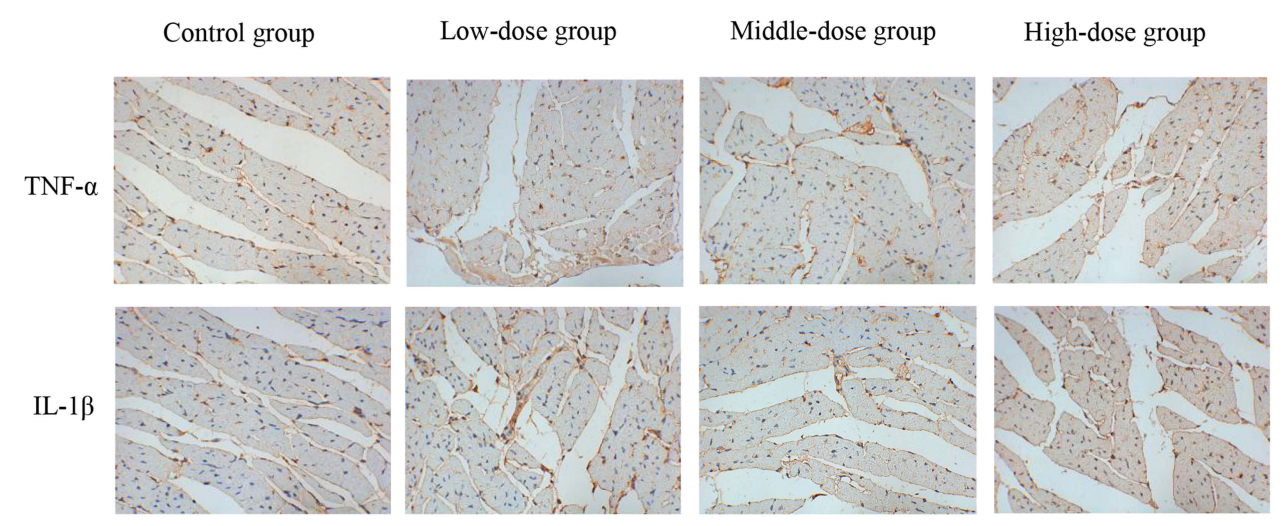

Figure II Expression of TNF- $\alpha$ and IL-I $\beta$ detected via immunohistochemistry in the heart sections at I20h (magnification $\times 400$ ). The positive color was tan.

Mouse had lots of advantages, such as inexpensive, readily available and its metabolism is similar to human. Therefore, mouse plays an important role in establish liver injury animal models. Considering the fact that it is easy to cause the mice death due to mistakenly entering the trachea by gavage, the method of intraperitoneal injection was selected for administration.

The research showed that with the increase of sodium cyclamate dosage and treated time, the liver damage became more obvious. The serum levels of ALT and AST were increased gradually. In addition, the serum level of AST was increased more obvious than ALT. But the serum level of ALT increased is prior to the AST. AST is mainly distributed in mitochondria. However, ALT is mainly distributed in the cytoplasm of liver epithelial cells. When mitochondria damaged, the serum level of AST will increased significantly. If the membrane of liver epithelial cells damaged, ALT is released into the blood. Therefore, in the past studies, the serum level of ALT is considered to be the most sensitive indicator of liver function. The present study also verified this point. The pathological results demonstrated that hepatocytes showed obvious ballooning changes in the low-dose $(3000 \mathrm{mg} / \mathrm{kg} / \mathrm{day}$, intraperitoneally) group at $168 \mathrm{~h}$ and the high-dose $(12,000 \mathrm{mg} / \mathrm{kg} / \mathrm{day}$, intraperitoneally) group at $24 \mathrm{~h}$, but in those dosage and treated time the myocardial bundle granular degeneration, ballooning changes and the renal tubules lumen expansion, basement membrane exposure, which could not used as the most appropriate dosage and treated time. In the middledose $(6000 \mathrm{mg} / \mathrm{kg} / \mathrm{day}$, intraperitoneally) group, some hepatocytes edema and ballooning changes from $24 \mathrm{~h}$ to $72 \mathrm{~h}$, but those were not obvious. Until $120 \mathrm{~h}$, the arrangement of liver cells was disordered, lots of hepatocytes edema and ballooning changes, a small amount of inflammatory cells infiltrated, the chromatin in nucleus and the cytoplasm reduced, which indicated that the typical acute liver injury began to appear after sodium cyclamate reached a measure of dosage and treated time. Moreover, it is not obvious damage to the heart and kidney tissues at this time.

The study suggested that the toxicity of sodium cyclamate to liver showed a dose-response and time-response relationship. The sodium cyclamate-induced acute DILI mouse model can be established by intraperitoneal injection of $6000 \mathrm{mg} / \mathrm{kg} /$ day sodium cyclamate for 5 days successfully. In this dosage and treated time, there is no obvious toxicity

Table I 4 The Expression of TNF- $\alpha$ and IL-I $\beta$ Protein in the Kidney at I20h (IOD/Area)

\begin{tabular}{|l|c|c|}
\hline Groups & TNF- $\alpha$ & IL-I $\beta$ \\
\hline Control group & $0.0096 \pm 0.0009$ & $0.0105 \pm 0.0010$ \\
Low-dose group & $0.0104 \pm 0.0011$ & $0.0107 \pm 0.0008$ \\
Middle-dose group & $0.0107 \pm 0.0011$ & $0.0119 \pm 0.001 I^{*}$ \\
High-dose group & $0.0117 \pm 0.0014^{*}$ & $0.0226 \pm 0.0009 * *$ \\
\hline
\end{tabular}

Notes: Data are presented as mean \pm standard deviation; $* \mathrm{P}<0.05$ vs control group; $* * \mathrm{P}<0.01$ vs control group. 


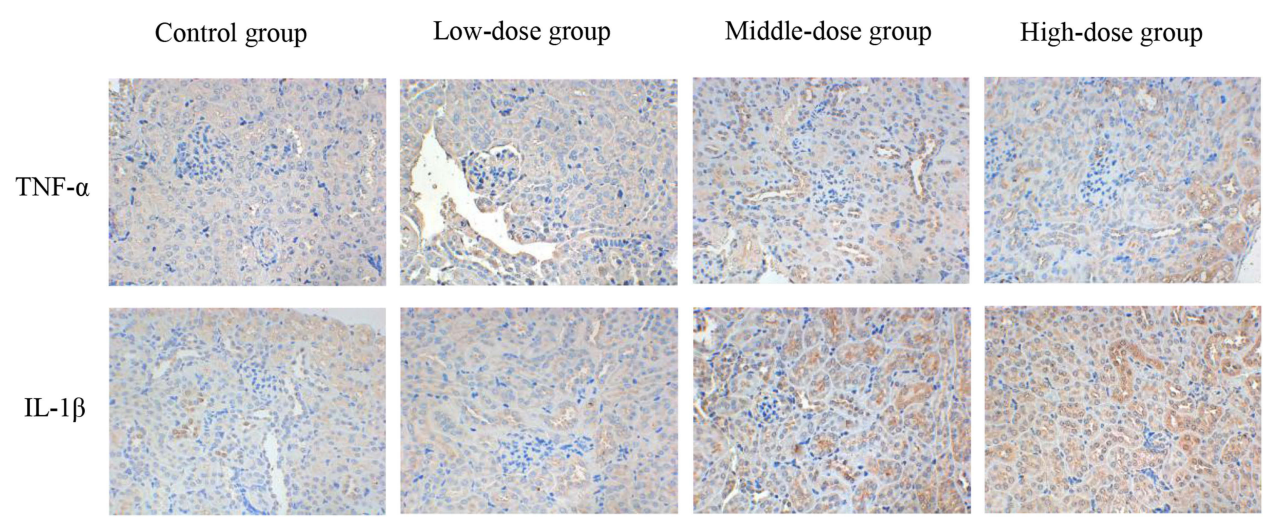

Figure 12 Expression of TNF- $\alpha$ and IL-I $\beta$ detected via immunohistochemistry in the kidney sections at I20h (magnification $\times 400$ ). The positive color was tan.

to heart and kidney. It has great specificity and low mortality, which proves that this acute DILI mouse model is stable. Besides, this method has the advantages of sensitive, easy, fast, economical and practical.

Nuclear factor $\kappa-\mathrm{B}(\mathrm{NF}-\kappa \mathrm{B})$ is a classical inflammatory signaling pathway. Previous studies found that activated NF- $\mathrm{kB}$ is stimulated to transfer from cytoplasm to nucleus and bind to transcription start site, which promotes the release of TNF- $\alpha$ and $\mathrm{IL}-1 \beta .^{27}$ However, the high expression of TNF- $\alpha$ and IL- $1 \beta$ could increase the expression of NF- $\mathrm{KB}$, then down regulate the metabolic activity and protein expression of CYP2E1, which involved in the process of liver injury. ${ }^{28}$ TNF- $\alpha$ also plays a key role in myocardial injury. It can directly inhibit myocardial contractility. The mechanism may be related to TNF- $\alpha$ activation of sphingomyelinase, proteolytic enzyme and inhibition of calcium influx. ${ }^{29} \mathrm{~A}$ large number of neutrophils gather in the damaged myocardium, release TNF- $\alpha$ and IL- $1 \beta$, while the increased TNF- $\alpha$ and IL- $1 \beta$ in the myocardium further activate immune cells and endothelial cells to produce other pro-inflammatory factors. ${ }^{30} \mathrm{TNF}-\alpha$ from the intrinsic cells of the kidney could inhibit the synthesis of nitric oxide in renal tubular epithelial cells, which induces renal inflammation and injury. ${ }^{31}$ The release of IL-1 $\beta$ makes neutrophils gather in the renal interstitium. ${ }^{32}$ After the renal interstitium damaged, causes the dysuria and impaired urine reabsorption. In present study showed that the expression of TNF- $\alpha$ and IL- $1 \beta$ increased gradually at $120 \mathrm{~h}$ with the increase of sodium cyclamate dosage, which indicated that the acute liver, heart and kidney injury induced by sodium cyclamate were closely related to the inflammatory response mediated by TNF- $\alpha$ and IL-1 $\beta$.

The main weakness of the study is the experimental research method is relatively basic. Future studies will conduct integrated research on genome, proteome, metabonomics and transcriptome, which will explore the toxicity mechanism of sodium cyclamate from the perspective of systemic toxicology and find new DILI biomarkers.

\section{Data Sharing Statement}

The datasets for this study are available from the corresponding authors on reasonable request.

\section{Ethics Approval and Consent to Participate}

All experiments were conducted in accordance with the National Institutes of Health Guide for the Care and Use of Laboratory Animals and were approved by the Animal Use and Protection Committee of University of South China.

\section{Acknowledgments}

Zhongtian Peng and Xialing Huang are co-corresponding authors.

\section{Funding}

No funding was received. 


\section{Disclosure}

The authors declare that they have no conflicts of interest for this work.

\section{References}

1. Syed M, Skonberg C, Hansen SH. Mitochondrial toxicity of diclofenac and its metabolites via inhibition of oxidative phosphorylation (ATP synthesis) in rat liver mitochondria: possible role in drug induced liver injury (Dili). Toxicol In Vitro. 2016;31:93-102. doi:10.1016/j. tiv.2015.11.020

2. Shen T, Liu Y, Shang J, et al. Incidence and etiology of drug-induced liver injury in Mainland China. Gastroenterology. 2019;156(8):2230-2241. e11. doi:10.1053/j.gastro.2019.02.002

3. Danjuma MI, Sajid J, Fatima H, Elzouki AN. Novel biomarkers for potential risk stratification of drug induced liver injury (Dili): a narrative perspective on current trends. Medicine. 2019;98(50):e18322. doi:10.1097/MD.0000000000018322

4. Leise MD, Poterucha JJ, Talwalkar JA. Drug-induced liver injury. Mayo Clin Proc. 2014;89(1):95-106. doi:10.1016/j.mayocp.2013.09.016

5. Sasaki YF, Kawaguchi S, Kamaya A, et al. The comet assay with 8 mouse organs: results with 39 currently used food additives. Mutat Res. 2002;519(1-2):103-119. doi:10.1016/s1383-5718(02)00128-6

6. Behrens M, Blank K, Meyerhof W. Blends of non-caloric sweeteners saccharin and cyclamate show reduced off-taste due to TAS2R bitter receptor inhibition. Cell Chem Biol. 2017;24(10):1199-1204.e2. doi:10.1016/j.chembiol.2017.08.004

7. Bopp BA, Sonders RC, Kesterson JW. Toxicological aspects of cyclamate and cyclohexylamine. Crit Rev Toxicol. 1986;16(3):213-306. doi:10.3109/10408448609037465

8. Hoppmann NA, Gray ME, McGuire BM. Drug-induced liver injury in the setting of chronic liver disease. Clin Liver Dis. 2020;24(1):89-106. doi:10.1016/j.cld.2019.09.006

9. Lai RT, Chen CW, Yu YC. Several issues worthy of reference and discussion of 2019 edition of the European Association for the Study of the Liver guideline for drug-induced liver injury. Zhonghua Gan Zang Bing Za Zhi. 2019;27(11):910-912. doi:10.3760/cma.j.issn.1007-3418.2019.11.018

10. Suh JI. Drug-induced liver injury. Yeungnam Univ J Med. 2020;37(1):2-12. doi:10.12701/yujm.2019.00297

11. Liu LW, Zhao XY, Jia JD. [EASL clinical practice guidelines recommendations for drug-induced liver injury in 2019]. Zhonghua Gan Zang Bing Za Zhi. 2019;27(6):420-423. Chinese. doi:10.3760/cma.j.issn.1007-3418.2019.06.006

12. Sadoh WE, Eregie CO, Nwaneri DU, Sadoh AE. The diagnostic value of both troponin T and creatinine kinase isoenzyme (CK-MB) in detecting combined renal and myocardial injuries in asphyxiated infants. PLoS One. 2014;9(3):e91338. doi:10.1371/journal.pone.0091338

13. Zhang CJ, Pei XL, Song FY, et al. Early anthracycline-induced cardiotoxicity monitored by echocardiographic Doppler parameters combined with serum hs-cTnT. Echocardiography. 2017;34(11):1593-1600. doi:10.1111/echo.13704

14. Ftouh S, Lewington A. Prevention, detection and management of acute kidney injury: concise guideline. Clin Med. 2014;14(1):61-65. doi:10.7861/ clinmedicine.14-1-61

15. Li M, Sun Q, Li S, et al. Chronic restraint stress reduces carbon tetrachloride-induced liver fibrosis. Exp Ther Med. 2016;11(6):2147-2152. doi:10.3892/etm.2016.3205

16. Komolkriengkrai M, Nopparat J, Vongvatcharanon U, Anupunpisit V, Khimmaktong W. Effect of glabridin on collagen deposition in liver and amelioration of hepatocyte destruction in diabetes rats. Exp Ther Med. 2019;18(2):1164-1174. doi:10.3892/etm.2019.7664

17. Tian F, Liu Y, Gao J, et al. Study on the association between TGF- $\beta 1$ and liver fibrosis in patients with hepatic cystic echinococcosis. Exp Ther Med. 2020;19(2):1275-1280. doi:10.3892/etm.2019.8355

18. Mohi-Ud-Din R, Mir RH, Sawhney G, Dar MA, Bhat ZA. Possible pathways of hepatotoxicity caused by chemical agents. Curr Drug Metab. 2019;20(11):867-879. doi:10.2174/1389200220666191105121653

19. Abd-Elhakim YM, Ghoneim MH, Khairy MH, Eissa SA. Single or combined protective and therapeutic impact of taurine and hesperidin on carbon tetrachloride-induced acute hepatic injury in rat. Environ Sci Pollut Res Int. 2020;27(12):13180-13193. doi:10.1007/s11356-020-07895-1

20. Rani V, Verma Y, Rana K, Rana SVS. Zinc oxide nanoparticles inhibit dimethylnitrosamine induced liver injury in rat. Chem Biol Interact. 2018;295:84-92. doi:10.1016/j.cbi.2017.10.009

21. Yang W, Hao Y, Hou W, et al. Jieduan-Niwan formula reduces liver apoptosis in a rat model of acute-on-chronic liver failure by regulating the E2F1-mediated intrinsic apoptosis pathway. Evid Based Complement Alternat Med. 2019;2019:8108503. doi:10.1155/2019/8108503

22. Lin L, Guan H, Li R, et al. Auriculatone sulfate effectively protects mice against acetaminophen-induced liver injury. Molecules. $2019 ; 24(20): 3642$. doi:10.3390/molecules24203642

23. Durán Agüero S, Angarita Dávila L, Escobar Contreras MC, Rojas Gómez D, de Assis Costa J. Noncaloric sweeteners in children: a controversial theme. Biomed Res Int. 2018;2018:4806534. doi:10.1155/2018/4806534

24. Janvier S, Goscinny S, Le Donne C, Van Loco J. Low-calorie sweeteners in food and food supplements on the Italian market. Food Addit Contam Part B Surveill. 2015;8(4):298-308. doi:10.1080/19393210.2015.1094829

25. Arnold DL. Toxicology of saccharin. Fundam Appl Toxicol. 1984;4(5):674-685. doi:10.1016/0272-0590(84)90088-5

26. Knowles MA, Jani H, Hicks RM. Induction of morphological changes in the urothelium of cultured adult rat bladder by sodium saccharin and sodium cyclamate. Carcinogenesis. 1986;7(5):767-774. doi:10.1093/carcin/7.5.767

27. Babbitt SE, Sutherland MC, San Francisco B, Mendez DL, Kranz RG. Mitochondrial cytochrome c biogenesis: no longer an enigma. Trends Biochem Sci. 2015;40(8):446-455. doi:10.1016/j.tibs.2015.05.006

28. Lin X, Huang R, Zhang S, et al. Methyl helicterate protects against CCl4-induced liver injury in rats by inhibiting oxidative stress, NF- $\kappa B$ activation, Fas/FasL pathway and cytochrome P4502E1 level. Food Chem Toxicol. 2012;50(10):3413-3420. doi:10.1016/j.fct.2012.07.053

29. Vincent JL; International Sepsis Forum. Hemodynamic support in septic shock. Intensive Care Med. 2001;27(Suppl 1):S80-S92. doi:10.1007/ pl00003799

30. Aly H, Khashaba MT, El-Ayouty M, El-Sayed O, Hasanein BM. IL-1 beta, IL-6 and TNF-alpha and outcomes of neonatal hypoxic ischemic encephalopathy. Brain Dev. 2006;28(3):178-182. doi:10.1016/j.braindev.2005.06.006

31. Zhang J, Patel MB, Griffiths R, et al. Tumor necrosis factor- $\alpha$ produced in the kidney contributes to angiotensin II-dependent hypertension. Hypertension. 2014;64(6):1275-1281. doi:10.1161/HYPERTENSIONAHA.114.03863 
32. Vilaysane A, Chun J, Seamone ME, et al. The NLRP3 inflammasome promotes renal inflammation and contributes to CKD. J Am Soc Nephrol. 2010;21(10):1732-1744. doi:10.1681/ASN.2010020143

\section{Publish your work in this journal}

The Journal of Inflammation Research is an international, peer-reviewed open-access journal that welcomes laboratory and clinical findings on the molecular basis, cell biology and pharmacology of inflammation including original research, reviews, symposium reports, hypothesis formation and commentaries on: acute/chronic inflammation; mediators of inflammation; cellular processes; molecular mechanisms; pharmacology and novel anti-inflammatory drugs; clinical conditions involving inflammation. The manuscript management system is completely online and includes a very quick and fair peer-review system. Visit http://www.dovepress.com/testimonials.php to read real quotes from published authors.

Submit your manuscript here: https://www.dovepress.com/journal-of-inflammation-research-journal 